Stilistika: Jurnal Bahasa, Sastra, dan Pengajarannya

ISSN 2527-4104

Vol. 1 No.2, 1 Oktober 2016

\title{
KETIDAKLANGSUNGAN EKSPRESI DALAM KUMPULAN PUISI MANUSIA ISTANA KARYA RADHAR PANCA DAHANA (KAJIAN STILISTIKA)
}

\author{
Siti Aisyah ${ }^{1}$ dan Noor Indah Wulandari ${ }^{2}$.
}

1. SMA Kartika V-3 Banjarmasin, Jalan Sutoyo S, Banjarmasin, Kalimantan Selatan;

2. STKIP PGRI Banjarmasin, Jalan Sultan Adam, komp. H. Iyus Rt. 23 No. 18 Banjarmasin, Kalimantan Selatan. e-mail: indahstkipbjm190.com

\begin{abstract}
ABSTRAK
Penelitian ini membahas tentang ketidaklangsungan ekspresi dalam kumpulan puisi Manusia Istana. Tujuan penelitian ini untuk (a) mendeskripsikan metafora dan metonimi pada kumpulan puisi Manusia Istana karya Radhar Panca Dahana, yang merupakan ketidaklangsungan ekspresi puisi yang disebabkan oleh penggantian arti; (b) mendeskripsikan keambiguitasan, kontradiksi, dan nonsense pada kumpulan puisi Manusia Istana karya Radhar Panca Dahana, yang merupakan ketidaklangsungan ekspresi puisi yang disebabkan oleh penyimpangan arti, dan (c) mendeskripsikan persajakan (rima), enjambemen dan tipografi pada kumpulan puisi Manusia Istana karya Radhar Panca Dahana, yang merupakan ketidaklangsungan ekspresi puisi yang disebabkan oleh penciptaan arti.

Pendekatan yang digunakan dalam penelitian ini adalah pendekatan stilistika dengan menggunakan metode kualitatif. Sumber data yang digunakan dalam penelitia ini adalah puisi Manusia Istana karya Radhar Panca Dahana yang diterbitkan oleh PT Bentang Pustaka Yogyakarta tahun 2015 dengan tebal 166 halaman dengan 32 judul puisi. Adapun judul puisi yang dianalisis sebanyak 5 buah judul puisi. Teknik yang digunakan dalam penelitian ini adalah teknik dokumentasi. Kemudian untuk menganalisis data penelitian ini dilakukan dengan tahap awal, pengkodean, dan klasifikasi.

Hasil penelitian inidisimpulkan sebagai berikut. Analisis ketidaklangsungan ekspresi terhadap lima judul puisi karya Raddhar Panca Dahana terdiri atas: (a) Penggantian arti yang terdiri dari: tujuh buah metafora dan sembilan buah metonimi; (b) Penyimpangan arti yang terdiri dari: sepuluh buah keambiguitasan, lima buah kontardiksi, dan enam buah nonsense, dan (c) Penciptaan arti yang terdiri dari: rima dengan konsonan $h, k, m$ dan vocal $a, i, u$ yang mendominasi, empat buah enjambemen, dan tipografinya menggunakan huruf besar-kecil, menggunakan banyak tanda baca, sebagian lariknya menjorok ke dalam, sebagian puisi menggunakan angka-angka.
\end{abstract}

Kata kunci: ketidaklangsungan ekspresi, puisi, kajian stilistika. 
Stilistika: Jurnal Bahasa, Sastra, dan Pengajarannya

ISSN 2527-4104

115

Vol. 1 No.2, 1 Oktober 2016

\section{PENDAHULUAN}

Karya sastra seperti puisi sering digunakan sebagai media untuk mengungkapkan perasaan. Ketika seseorang mengungkapkan perasaannya maka tidak ada batasan dalam menyampaikan perasaan tersebut, sehingga penyampaian mengenai sesuatu sering mempunyai banyak arti. Melihat fenomena seperti itu, terkadang orang pada umumnya menganggap hal tersebut salah dalam penulisan.

Dalam hal ini peneliti menitikberatkan penelitiannya terhadap ketidaklangsungan ekspresi pada puisi dengan menggunakan kajian stilistika. "Kajian Stilistika pada prinsipnya selalu mengkaji pemakaian bahasa yang khas atau istimewa, yang merupakan ciri khas penulis, aliran sastra atau yang menyimpang dari bahasa sehari-hari atau dari bahasa yang dianggap normal, baku, dan lain-lain" (Teeuw, 1984:72 dalam Tarsyad, 2011:1-2).

Analisis ketidaklangsungan ekpresi yang disebabkan oleh peggantian arti, penyimpangan arti, dan penciptaan arti, dengan menggunakan kajian stilistika ini sebuah puisi mampu dijelaskan dan dipahami secara keseluruhan, karena dalam kajian stilistika akan mengungkapkan bagaimana pemakaian gaya bahasa dalam sebuah karya sastra khususnya puisi. (Pradopo, 2012: 209-210) mengatakan bahwa "dalam sastra ada yang merupakan konvensi bahasa tambahan. Konvensi bahasa tambahan dalam sastra diantaranya konvensi bahasa kiasan, pesajakan pembagian bait, enjambemen, dan tipografi".

Berkaitan dengan hal tersebut, maka peneliti akan melakukan analisis terhadap kumpulan puisiManusia Istana karya Radhar Panca Dahana. Banyak orang yang mengapresiasi karyanya khususnya para politisi. Karya Radhar Panca Dahana yang berjudul Manusia Istana membicarakan tentang dunia politik.

"Dalam sastra ada yang merupakan konvensi bahasa tambahan. Konvensi bahasa tambahan dalam sastra diantaranya konvensi bahasa kiasan, pesajakan pembagian bait, enjambemen, dan tipografi" (Pradopo, 2012: 209-210).(Riffatere, 1987:1) mengemukakan konvensi tambahan puisi itu bahwa puisi itu menyatakan pengertian-pengertian atau hal-hal secara tidak langsung, yaitu menyatakan suatu hal dan berarti yang lain. Dengan demikian, bahasa puisi memberikan makna lain dari pada bahasa biasa. Menurutnya, ketidaklangsungan pernyataan puisi itu disebabkan oleh tiga hal yaitu penggatian arti, penyimpangan arti, dan penciptaan arti.(Riffaterre, 1978:2) "penggantian arti disebabkan oleh penggunaan metafora dan metonimi. Dalam penggantian arti ini suatu kata (kiasan) berarti yang lain (tidak arti sesungguhnya)". 
Stilistika: Jurnal Bahasa, Sastra, dan Pengajarannya

ISSN 2527-4104

116

Vol. 1 No.2, 1 Oktober 2016

\title{
METODE
}

Penelitian mengenai ketidaklangsungan ekspresi dalam puisi Manusia Istana karya Radhar Panca Dahana ini, peneliti menggunakan pendekatan penelitian stilistika.

Metode yang digunakan untuk menganalisis ketidaklangsungan ekspresi yang mampu menimbulkan penggantian arti, penyimpangan arti, dan penciptaan arti yang terdapat dalam kumpulan puisi Manusia Istana karya Radhar Panca Dahana adalah metode penelitian kualitatif. Metode ini dilakukan dengan cara menganalisis naskah puisi yang disesuaikan dengan landasan teori dan latar belakang yang terdapat dalam penelitian ini serta membuat penjelasan yang lebih mendalam terhadap objek kajian

.Teknik analisis data yang digunakan untuk menganalisis ketidaklangsungan ekspresi pada kumpulan puisi Manusis Istana karya Radhar Panca Dahana menggunakan teori. Bogdan dan Biklen, 2007 (dalam Gunawan, 2015:210) yang tersebut. (Ratna, 2015:47), mengatakan bahwa "penelitian kualitatif dalam sastra sumber datanya adalah karya, naskah dan data penelitiannya sebagai data formal adalah kata-kata, kalimat, dan wacana”.

"Data penelitian kualitatif diperoleh dari sumber data dengan menggunakan teknik pengumpulan data dalam kategori teknik noninteraktif yang meliputi analisis isi dokumen dan arsip" (Gunawan, 2015:142). Teknik pengumpulan data yang digunakan dalam penelitian ini adalah dokumentasi, karena data berupa teks puisi dalam kumpulan puisi Manusia Istana karya Radhar Panca Dahana yang berjumlah 31 Judul puisi, namun peneliti hanya meneliti 5 judul puisimengatakan bahwa analisis data adalah proses pencarian dan pengaturan secara sistematik hasil catatan-catatan, dan bahan-bahan yang dikumpulkan untuk meningkatkan pemahaman terhadap semua hal yang dikumpulkan dan memungkinkan menyajikan apa yang ditemukan.

\section{HASIL DAN PEMBAHASAN}

\section{Ketidaklangsungan Ekspresi Puisi "Di Toilet Istana"}

\author{
DI TOILET ISTANA \\ bahkan kertas tisu \\ harga sebulan susu anakku. \\ pukul empat sepuluh sore \\ dendang lagu membentak tembok tua \\ lampu Kristal menggerutu \\ siapa mengoyak wibawa sunyi? \\ "oo...tuan rumah tengah bernyanyi..." \\ wastafel ketus membeku \\ sabun cair celoteh tak tentu \\ dan peturasan menggerojok air
}


Vol. 1 No.2, 1 Oktober 2016

dengan wangi mantan pacarku

di dinding, cermin besar tertawa

"berapa sudah orang besar

mematut plastic wajahnya

mengemas iblis ambisinya

di bening jidatku, tanpa tersipu"

aku tersenyum,

meraba air hangat

merasa lembutnya mimpi istriku

dan membasahi rambut

"laiknya menteri akan diganti,"

hahaha ... keramik impor terpingkal

cermin terbahak tawa

aku menyerapah sumpah

tapi senandung itu,

desibelnya menggetarkan

perempuan di kanvas sujoyono

dan kuda raden saleh memekik

menerobos lubang air

tempat ludah menyesali kedatanganku

aku meremas handuk hangat

seperti meremas rezeki keluarga

aku pamit pada air seniku

karena acara segera selesai

lagu mencari koda yang tak usai

toliet itu tersenyum

parfumnya menyengat, membuat

foto di dompetku cemburu

aku juga tertawa

tak mengira, 20 menit

aku berteater dengan toilet istana

panggung paling merangsang

sebab hati dan kepalanya terang

empat tigapuluh sore

kubelakangi pintu panggung itu

yang menutup tanpa debam

yang tersinggung tanpa dendam

cuma suara lagu terus mendenngung

terpenjara dalam panggung 
Stilistika: Jurnal Bahasa, Sastra, dan Pengajarannya

ISSN 2527-4104

118

Vol. 1 No.2, 1 Oktober 2016

memantul antara cermin dan

peturasan, memberi hiburan

bagi orang besar, mana saja

yang segera masuk bercermin

dan tak menyesali

kotorannya pergi

Puisi "Di Toilet Istana" berjumlah sepuluh bait, jumlah larik dalam setiap bait bervariasi. Setiap bait terdiri dari dua sampai dengan delapan larik. jumlah larik keseluruhan ada lima puluh lima larik.

\section{Penggantian Arti}

\section{Metafora}

Puisi "Di Toilet Istana",terdapat metafora pada judul dan bait kedelapan larik ketiga aku berteater dengan toilet istana. Kata toilet istana merupakan kiasan yang menyatakan tempat yang kecil dan bau tetapi seperti halnya istana (plbt81r3h10).

\section{Metonimi}

Puisi "Di Toilet Istana", terdapat metonimi pada bait kelima larik ketigaperempuan di kanvas sujoyono. Kata kanvas tersebut merupakan metonimi, pembaca akan langsung mengetahui bahwa yang dimaksudkan pengarang adalah lukisan, karena kanvas merupakan media yang biasanya digunakan untuk melukis. Hal tersebut di dukung oleh kata yang mengikutinya yaitu perempuan, yang semakin memperkuat bahwa itu merupakan lukisan perempuan yang dibuat oleh sujoyono. Selain lukisan perempuan ada juga lukisan kuda, seperti larik berikutnya dan kuda raden saleh memekik/ menerobos air (p1bt5lr3h9). Bait kesepuluh larik kedelapan kotorannya pergi juga terdapat metonimi. Kata kotorannya pada puisi tersebut yaitu dosa seseorang. Dosa identik dengan suatu hal yang kotor yang pernah dilakukan seseorang, sehingga kata dosa dan kotor mempunyai pertautan yang dekat dan relasional. Imbuhan -nya pada kotorannya merujuk kepada manusia atau seseorang (p1bt101r8h10).

\section{Penyimpangan Arti Ambiguitas}

Puisi "Di Toilet Istana", keambiguitasan terdapat pada judul kata di Toilet Istana mempunyai makna ganda, makna yang pertama menujukkan bahwa toilet tersebut ada di istana dan makna kedua toilet tersebut seperti istana (p1bt81r3h10). Kata toilet istana juga terdapat pada bait kedelapan larik ketiga. Bait kedua larik pertama juga terdapat keambiguitasan pukul empat sepuluh sore. kata pukul empat sepuluh memiliki makna ganda yaitu pukul empat lewat sepuluh dan pukul empat kurang sepuluh (p1bt2lr1h9). Hal tersebut juga terjadi pada bait kesembilan larik pertama empat tiga puluh sore, kata empat tiga puluh juga memiliki makna ganda yaitu empat lewat tiga puluh dan empat kurang tiga puluh (p1bt9lr1h10). Keambiguitasan juga terdapat pada bait ketujuh larik kedua parfumnya menyengat, frase tersebut mempunyai makna ganda yaitu parfumnya yang menyengat itu bisa bau 
Stilistika: Jurnal Bahasa, Sastra, dan Pengajarannya

ISSN 2527-4104

Vol. 1 No.2, 1 Oktober 2016

bisa juga wangi. Larik sebelumnya mengatakan bahwa toilet itu tersenyum seolah toiletpun senang tersenyum wangi parfumnya. Hal tersebut juga didukung oleh larik selanjutnya yaitu foto di dompetku cemburu, bahkan foto yang ada di dompetnya cemburu dengan wangi yang menyengat itu.

Kontradiksi

Puisi " Di Toilet Istana",kontradiksi terdapat pada bait keempat.

(...)

aku tersenyum,

meraba air hangat

merasa lembutnya mimpi istriku

dan membasahi rambut

"Iaiknya menteri akan diganti,"

hahaha ... keramik impor terpingkal

cermin terbahak tawa

aku menyerapah sumpah

(...)

Pernyataan puisi tersebut pengarang menjelaskan bahwa si aku dalam keadaan baik-baik saja, si aku bisa tersenyum, merasakan kelembutan dan merasa nyaman. Seperti pada kalimat berikut aku tersenyum/ meraba air hangat/ merasa lembutnya mimpi istriku/ dan membasahi rambut. Kemudian larik selanjutnya laiknya menteri akan diganti, sesungguhnya dia menyampaikan kekesalannya atau suatu bentuk protes terhadap para menteri tidak menunjukkan kinerjanya. Begitu pula dengan larik berikutnya hahaha ... keramikimporterpingkal/ cerminterbahaktawa melihat keadaan yang bahagia seperti itu, si aku bahkan tidak merasa bahagia, sampai puncak kekesalannya dia melontarkan sumpah-sumpah seperti pada kalimat "akumenyerapahsumpah" (p1bt4lr1-8h9). Penggalan puisi "Di Toilet Istana" di bawah ini juga merupakan kontradiksi.

(...)

aku memeras handuk hangat

seperti memeras rezeki keluarga

(...)

\section{Nonsense}

Puisi "Di Toilet Istana" nonsense terdapat pada bait kedua larik kelima " $0 .$. tuan rumah tengah bernyanyi..." . kata00... tersebut secara linguistik tidak memiliki arti, kata tersebut diciptakan oleh pengarang. Meskipun tidak memiliki arti secara linguistik tetapi pada puisi kata tersebut mengandung makna. Kata 00... pada puisi tersebut bermakna seruan yang digunakan untuk menambah kesan pada puisi dan menghidupkan suasana (p1bt2lr5h9).

\section{Penciptaan Arti}

\section{Rima}

Puisi “Di Toilet Istana", didominasi oleh pengulangan bunyi konsonan " $m$ " yang menggambarkan suasana tertekan dalam menjalani kehidupan yang di atur oleh orang-orang besar yang hidup dalam kemewahan. seperti pada kata membentak, 
Stilistika: Jurnal Bahasa, Sastra, dan Pengajarannya

ISSN 2527-4104

Vol. 1 No.2, 1 Oktober 2016

membeku, mantan, mematut, mengemas, tersenyum, meraba, memeras, mimpi, membasahi, menteri, menyerapah, meremas, mencari, memyengat, membuat, menutup, merangsang, debam, dendam, mendengung, memantul, memberi, mana, masuk, meneyesali. Selain itu juga terdapat pengulangan bunyi vokal " $u$ " menggambarkan suasana kemarahan sebagai bentuk protes terhadap orang-orang yang hidup dengan kecurangan dan merugikan orang lain seperti kata tisu, susu, anakku, lagu, menggerutu, membeku, tentu, pacarku, tersipu, istriku, itu, kedatanganku, seniku, cemburu, pintu (p1h9-10).

\section{Enjambemen}

Pada puisi "Di Toilet Istana", terjadi enjambemen atau pemotongan kalimat di akhir larik kemudian meletakkan potongan itudi awal larik berikutnya, seperti bait kesepuluh larik keempat dan kelima berikut.

\section{(...) \\ memantul antara cermin dan \\ peturasan, memberi hiburan \\ (...)}

Penggalan puisi tersebut memantul antara cermin danterjadi enjambemen dengan larik berikutnya peturasan, memberi hiburan. Seharusnya memantul antara cermin danpeturasan dan larik berikutnya memberi hiburan. Hal tersebut dimaksudkan agar tanda baca yang dibubuhkan tidak berada di akhir larik dan menimbulkan penekanan pada kata peturasan (p1bt10lr3-4h10).

\section{Tipografi}

Puisi "Di Toilet Istana", bentuk tipografinya menggunakan huruf kecil, sebagian lariknya menjorok kedalam, dan menggunakan beberapa tanda baca pada kata-kata tertentu, tipografi seperti itu dibuat untuk memperindah tampilan puisi tersebut (p1h9-10).

\section{Pembahasan Puisi “Di Toilet Istana”}

Puisi "Di Toilet Istana" membicarakan tentang kehidupan politik di suatu tempat, dimulai dengan suatu pernyataan, seperti kata $d i$ - pada judul tersebut yang menandakan tempat dan ditegaskan pula bahwa tempat tersebut adalah toilet istana. Di toilet istana memiliki makna bahwa di tempat itu ada yang sedang terjadi. Walaupun hanya sebuah toilet, namun kata istana menegaskan bahwa sebuah toilet yang tidak berharga atau tempat yang kotor menjadi tempat yang mewah bahkan tisupun menjadi sangat berhargaseperti yang digambarkan pada larik pertama dan kedua bahkan kertas tis/ harga sebulan susu anakku.

Meskipun puisi "Di Toilet Istana" kata toilet istana hanya ada satu kali dan terletak pada bait ke delapan larik ketiga, tetapi gambaran sebuah toilet ada pada larik-larik sebelumnya. Seperti kata wastafel, sabun cair, cermin, menggerojok air, air hangat, keramik, begitulah gambaran sebuah toilet istana. Sebuah toilet yang sering dianggap sebagai tempat yang kotor juga dapat menarik perhatian jika diisi dengan hal-hal yang mewah. Begitulah kehidupan di istana walaupun hanya sekedar toilet. Namun semua itu tidak selalu berujung baik, kehidupan yang mewah juga 
dapat menyesatkan seseorang seperti pernyataan bait keenam larik pertama dan kedua aku memeras handuk hangat/ seperti memeras rezeki keluarga, larik-larik tersebut menegaskan bahwa ketika seseorang dengan segala kenikmatannya, secara tidak sadar ada hak orang lain di dalamnya, kata rezeki keluarga bukan hanya ditujukan pada keluarga sebenarnya tetapi kepada rakyat.

Kehidupan didalam istana hanyalah sebuah sandiwara seperti pada bait kedelapan larik ketiga aku berteater dengan toilet istana. Dunia politik memang identik dengan kebohongan dan kecurangan karena banyak hal-hal yang menggiurkan bagi para pelaku politik seperti bait kedelapan larik ketiga panggung paling meranggsang. Kemewahan yang didapat dengan cara seperti itu hanya akan menyesatkan pada akhirnya seperti pada bait kesepuluh larik kedua terpenjara dalam panggung. Namun, dalam bait kesepuluh larik keenam sampai larik kedelapan yang segera masuk bercermin/ dan tak menyesali kotorannya pergi. Kata bercermi, tak menyesali, dan kotorannya menjelaskan bahwa tak ada penyesalan dalam diri untuk sebuah dosa yang telah dilakukan.

\section{PENUTUP Simpulan}

Berdasarkan hasil pembahasan yang telah dikemukakan pada bab sebelumnya, maka penelitian ini dapat disimpulkan sebagai berikut. Analisis ketidaklangsungan ekspresi terhadap lima judul puisi karya Raddhar Panca Dahana terdiri dari.

a. Penggantian arti yang terdiri dari: tujuh buah metafora dan sembilan buah metonimi.

b. Penyimpangan arti yang terdiri dari: sepuluh buah keambiguitasan, lima buah kontardiksi, dan enam buah nonsense.

c. Penciptaan arti yang terdiri dari: rima dengan konsonan $h, k, m$ dan vocal $a$, $i$, $u$ yang mendominasi, empat buah enjambemen, dan tipografinya menggunakan huruf besar-kecil, menggunakan banyak tanda baca, sebagian lariknya menjorok ke dalam, sebagian puisi menggunakan angka-angka.

\section{Saran}

Saran-saran yang diharapkan sebagai berikut.

a. Pembaca

Setelah membaca hasil penelitian tersebut, dapat menambah pengetahuan keilmuan tentang ketidaklangsungan ekspresi puisi yang terdapat dalam kumpulan puisi Manusia Istana karya Radhar Panca Dahana. Penelitian ini juga memudahkan pembaca untuk memperdalam teori ketidaklangsungan ekspresi. Oleh karena itu, pembaca juga disarankan untuk membaca buku yang berjudul Pengkajian Puisi, Stilistika pada puisi, Teori Penulisan Puisi, dan lain-lain guna memperdalam pemahaman mengenai ketidaklangsungan ekspresi.

b. Peneliti selanjutnya 
Peneliti selanjutnya diharapkan dapat memperdalam penelitian ini, mengingat masih adanya beberapa judul puisi yang belum dianalisis dengan mengadakan penelitian lanjutan mengenai ketidaklangsungan ekspresi yang terdapat dalam kumpulan puisi Manusia Istana karya Radhar Panca Dahana. Hal ini bertujuan agar dapat memperkaya pemahaman keilmuan khususnya ketidaklangsungan ekspresi puisi.

\section{DAFTAR PUSTAKA}

Dahana, R. P. (2015). Manusia Istana: Sekumpulan Puisi Politik. Yogyakarta: Bentang Pustaka.

Ganie, T. N. (2013). Teori Menulis Puisi. Banjarmasin: Pustaka Banua.

Gunawan, I. (2015). Metode Penelitian Kualitatif Teori dan Praktik, Cetakan ketiga. Jakarta: Bumi Aksara.

Pradopo, R. D. (2012). Pengkajian Puisi Cetakan Ketigabelas. Yogyakarta: Gajah Mada University.

Riffaterre, M. (1978). Semiotics Of Poetry. London: University Press.

Santoso, A. (2014). Gaya Bahasa dan Makna dalam Kumpulan Puisi Bulu Tangan Karya Tajuddin Noor Ganie. STKIP PGRI Banjarmasin: Skripsi tidak dipubikan.

Tarsyad, T. E. (2011). Kajian Stilistika: Puisi Sapardi Djoko Damono. Banjarmasin: Tahura Media.

Tim, P. (2015). Pedoman Penulisan Skripsi. Banjarmasin: STKIP PGRI diterbitkan kalangan sendiri.

Zaidan, A. R. (2007). Kamus Istilah Sastra Cetakan Ketiga. Jakarta: Balai Pustaka. 